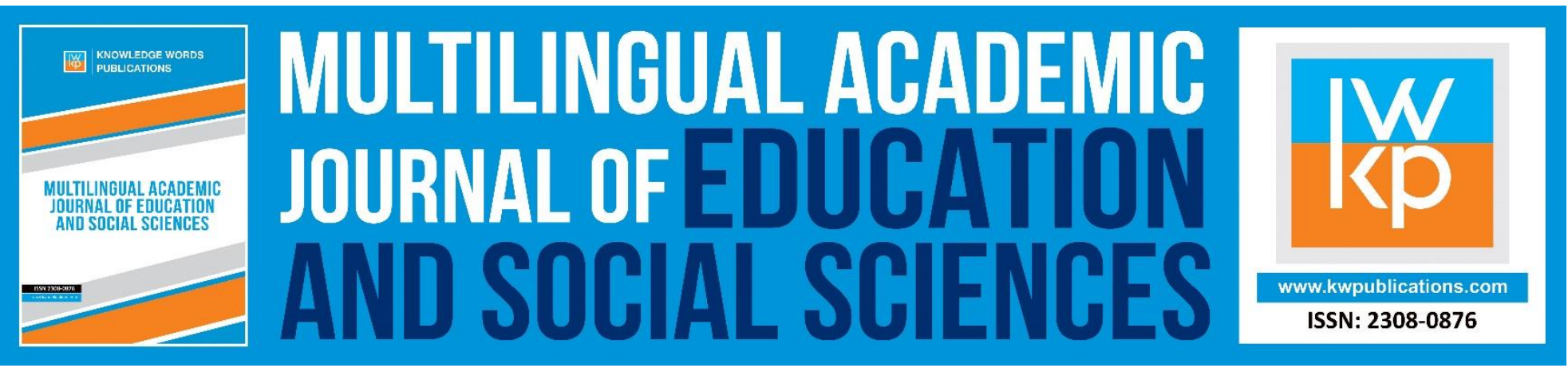

\title{
Teaching a Second or a Foreign Language to Middle School Students with ADHD: Modern Greek Taught as in the USA as an Example
}

\section{Alex Colombos}

To Link this Article: http://dx.doi.org/10.46886/MAJESS/v6-i1/3772

DOI: 10.46886/MAJESS/v6-i1/3772

Received: 03 August 2018, Revised: 06 September 2018, Accepted: 07 October 2018

Published Online: 22 November 2018

In-Text Citation: (Colombos, 2018)

To Cite this Article: Colombos, A. (2018). Teaching a Second or a Foreign Language to Middle School Students with ADHD: Modern Greek Taught as in the USA as an Example. Multilingual Academic Journal of Education and Social Sciences, 6(1), 1-11.

\section{Copyright: (c) The Authors 2018}

Published by Knowledge Words Publications (www.kwpublications.com)

This article is published under the Creative Commons Attribution (CC BY 4.0) license. Anyone may reproduce, distribute, translate and create derivative works of this article (for both commercial and non-commercial purposes), subject to full attribution to the original publication and authors. The full terms of this license may be seen at: http://creativecommons.org/licences/by/4.0/legalcode

Vol. 6, No. 1, 2018, Pg. 1 - 11 


\title{
Teaching a Second or a Foreign Language to Middle School Students with ADHD: Modern Greek Taught as in the USA as an Example
}

\author{
Alex Colombos \\ CRC, MA, MPS, MA Ed, Certified Social Studies (History) Teacher-Greek Studies Teacher- \\ Certified Rehabilitation Counselor
}

\begin{abstract}
A literature review was conducted in order to explore the international bibliography on middle school students with ADHD (Attention Deficit \& Hyperactivity Disorder) who learn a second or foreign language. In this case, the target language will be Modern Greek (GSL or Greek as a Second Language), but it can be used as an example for learning any second or foreign language, especially English that is ESL (English as a Second Language), since the student population here is English-speaking. In particular, the student population discussed in this paper is GreekAmericans of first and second or even third generation whose primary language is English. Professional knowledge of both English and Greek languages and deep understanding of the linguistic, cultural and pedagogical aspects of using both languages in the teaching praxis are required for the teacher to demonstrate effectively when teaching this particular student population. The study focused on the unique challenges of Modern Greek, especially in parochial Greek Schools and their day and mostly afterschool programs. The study took into consideration students who were both Greek and non-Greek descent, but most of them of Greek dissent. The challenge for students with ADHD who are in the middle school is that they enter puberty and at the same time they need to learn a hard language with a different alphabet than their first language, English. Those of Greek dissent often receive a lot of pressure from their demanding and over-protective Greek-American family and at the same time they get very frustrated and tired after a long day in the public school (afterschool) or after dealing with the demanding standardized test-oriented American curriculum, which is an issue for every Middle School student, so it is even worse for the student with low attention span, impulse-control deficit and hyperactivity.
\end{abstract}

Keywords: ADHD, Middle School, Greek Education, Afterschool, Modern Greek, ESL, GSL.

\section{What is ADHD?}

ADHD (Attention Deficit \& Hyperactivity Disorder) is listed in DSM IV-TR as Attention Deficit and Disruptive Behavior Disorders which are part of developmental disorders that are usually 
MULTILINGUAL ACADEMIC JOURNAL OF EDUCATION AND SOCIAL SCIENCES

Vol. 6, No. 1, 2018, E-ISSN: 2308-0876 @ 2018 KWP

diagnosed in childhood but can also continue to manifest themselves in adulthood and for life (APA, 2000 - ERIC, 1998). ADHD has two types: 1) inattention; 2) and hyperactivity-impulsivity (APA, 2000) and one may be diagnosed with either the one or the other. Some of the signs of either type have causing impairment have to be present before the age of 7 and may occur in at least two settings (e.g. home and school). Also impairment in social, academic, and occupational life has to be clinically evidenced and clearly unrelated to other Pervasive Developmental Disorder or any other mental disorder (e.g. psychotic, personality disorder, etc.) (APA, 2000).

At least six (6) symptoms of inattention may appear for the first type that persist for at least 6 month, such as failure to stick to detail, difficulty focusing on tasks and activities, failure to listen or respond, failure to follow instructions, difficulty organizing tasks, often avoiding or disliking tasks that require certain mental effort (e.g. homework), easily getting distracted by the environment or being too often forgetful in daily activities. For the second type (impulsivity and hyperactivity), six (6) of the following signs of hyperactivity and impulsivity may occur for at least six months. Symptoms of hyperactivity may include: fidgeting, leaving seat in classroom, running about or climbing up to inappropriate situation or as it happens to adolescents and adults, may appear restlessness and inappropriate subjective feelings (APA, 2000). Impulsivity symptoms may include: answering before questions are competed, often cannot wait turn, or often interrupting or intruding on others (e.g. games, conversations, etc.) (APA, 2000). National studies report that among parents of children age 6-13 years who have an emotional disturbance, $65 \%$ report their children also have ADHD. Studies supported by the Department of Education suggest genetic predisposition, as parents of $28 \%$ of children with learning disabilities report their children also have ADHD (US Dep. Of Ed., 2006).

\section{Middle School Students with ADHD}

It is not an accident that the most conservative studies estimate a percentage of students with ADD/ADHD to be at least 3\% to 5\% (ERIC, 1998). Smith (n.d.) supported that "as students grow older and reach middle school, they exhibit less activity than younger children with ADHD"...."may begin to decrease and develop into symptoms older adolescents and adults face, such as poor self-esteem, difficulty in relationships, and problems with drugs and/or alcohol)" (p. 1). However, in an empirical study of students, including preschoolers and eighth-graders, Hill (2011) concluded that those of them having ADHD are more likely to display aggressiveness and defiance then students without ADHD. Hill (2011) didn't make any distinction between preschoolers, first-graders, and eighth-graders either in the results or in the discussion/summary section. As having experience myself teaching both preschoolers and eight graders with ADHD, I agree that they both display aggressiveness and defiance, with more aggressiveness and defiance exhibited with eight graders.

\section{The Double Challenge: Middle School students with ADHD who learn a second or foreign language (i.e. Modern Greek)}

The first Greeks arrived in the US in Florida in 1768 building a community f 400 people, the New Smyrna (SAE, 2007-2012). In a census of 1980, there were almost 1 million Greeks in the US recorded or precisely 959.856 (SAE, 2007-2012). Modern Greek is taught in US and especially in New York were many Greeks live in three types of programs: a) as a foreign language in public 
MULTILINGUAL ACADEMIC JOURNAL OF EDUCATION AND SOCIAL SCIENCES

Vol. 6, No. 1, 2018, E-ISSN: 2308-0876 @ 2018 KWP

schools, where only language skills are taught with some elements of literature and history only for the most advanced classes; b) Greek parochial day schools, which function the same way with other private schools, but Modern Greek is taught, often in place of Spanish or as an additional foreign language with one 45-minute period every day; c) Afterschool Programs, which may run i) everyday; or II) most of them twice a week, and; d) the Saturday Programs, which run every Saturday from early in the morning to early in the afternoon.

Some afterschool Greek programs belong to partnership associations, networks, and communities so that quality assurance and effective treatment of various problems and needs may be enabled and facilitated as well as consumers may get easily networked with afterschool programs. However, many are missing from the list of such programs, such as the New York City Guide of the Partnership for Afterschool Education (PASE, n.d.). Day and Evening Parochial schools combine Modern Greek language with Greek history (ancient, byzantine, modern Greek), mythology, religion (Greek Orthodox Christian tradition/culture \& the Bible), Greek geography, Greek customs, Greek drama, poem recitation and artistic activities for various festivities and holidays, Byzantine Music/Chant, Greek music and dance. Students in New York public schools and charter schools affiliated with the New York City Department of Education follow the New York City Department of Education standards for assessing Modern Greek, such the Regents Exams held by the Greek Orthodox Archdiocese and overseen by the NYC Dep. Of Ed (Makedon, 2007).

Accommodations are offered for students with special needs, including ADHD, such as extra time (Makedon, 2007). Also in public schools were Greek is taught, support and accommodations are provided (NYS Dept. Of Ed, 1992). The Office of Special Education of the NYS Department of Education (1992) did not make a clear distinction in the 90s between emotionally disturbed and ADHD, but included accommodations in this categories, such as extra time for taking a test and it also described a certain system of getting the child identified and the interventions in a Greek version for parents who do not speak English. Assessment of Modern Greek as a Second Language similar to the Regents is also provided in Australia with accommodations for students with special needs, including ADHD (NYS Dep. Of Ed, 1992; Evangelinou-Yiannaki \& O'Donoghue, 2011; Thomson, 1997).

The teachers usually are of three types: teachers sent from Greece, in particular, form the Greek Ministry of Education, after they pass the English language exams and are motivated to migrate to other countries to teach Greek as they are paid both by the Greek government and the local Greek Orthodox church. Most of the Greek parochial schools are run by the Greek Orthodox Church. Some Greek education program organization occurs in Australia, as well. Bringing teachers from Greece is called "The second Teacher Greece Scheme" (Evangelinou-Yiannaki \& O'Donoghue, 2011). This type of Greek Education teacher has three stages of adaptation and rearrangement to the new environment after migrating from Greece to the New World: 1) idealism, 2) conflict, and 3) cooperation. First, they come with aspirations and visions as well as teaching styles, methods, mentalities, and lifestyles that may not be competent $o$ those in the new country. They come in conflict and they often may get disappointed or even return back to Greece. However, many of them are able to rearrange themselves and cooperate. One of the greatest challenges they face is dealing with emotional disturbance in children adolescents and especially ADHD (Evangelinou-Yiannaki \& O'Donoghue, 2011). 
MULTILINGUAL ACADEMIC JOURNAL OF EDUCATION AND SOCIAL SCIENCES

Vol. 6, No. 1, 2018, E-ISSN: 2308-0876 @ 2018 KWP

The other two types of teachers are those who are hired in US and are qualified or licensed teachers and the other is those who are not trained as teachers and they are hired with just a High School education and the credential of being native speakers of Modern Greek, though some of them do not even have those two qualifications! Many of them also become Principals depending on their connections with the community. Those problems in Greek-American parochial education are often attributed to underfunding (Zoupaniotis, 2012).

Many teachers who come from Greece do not speak English properly, they do not have enough education courses, they are hardly prepared, sometimes not even familiar with special education, and they just master the target subject they teach that is Greek (Kalyva, 2008), but they are not familiar with American or Australian society as it also happens in Australia, and they do not understand their students who are raised outside Greece and their primary language is English (Evangelinou-Yiannaki, \& O'Donoghue, 2011). They are also not trained in teaching Greek as a second language, but just as a native language. They also lack knowledge of all the other Greek subjects that go beyond Modern Greek language. Those teachers who are trained in US or Australia, may be licensed/certified by a state (e.g. NY), but they may not be trained to cover all Greek subjects or deal with special education students. The last category for teachers are not prepared at all and they rather tend to totally ignore and neglect servicing the needs of a child with special needs or just may not be able to identify them or they may not believe in special education, psychology, counseling or other areas of education and academic services (Papadopoulos, 2009).

Students with ADHD may be thought by the Greek parochial school staff or their parents are just being "too hyper," having a low conduct or morality or, especially for middle school students, as being average out-of-control teens and they may be very concerned about medication side effects, as they are very protective of their children and for a good reason, especially when it gets to medication (Papadopoulos, 2009). Inclusion in Greece is very limited usually to agencies rather than general education and for special education there are special schools (Kalyva, 2008; Spyridakis, 1981). Also, in Cyprus, inclusion is not really well established and expanded and it is rather closer to the Greek model with some better organization and funding, though (Spyridakis, 1981). Some teachers or Principals may think the student's behavior may relate to his/her family or upbringing or being just a "phase" of their developmental stage. Kalyva (2008) reports that in Greece, lack of general education teacher's knowledge of child psychology and special education lead to students' being labeled "naughty", " brat", "spoiled" and so on (Kalyva, 2008). Many Greeks in Greece and Cyprus may think that way and many of the parents of school staff that come from those countries may bring their mentality to the states.

Studies show that Greeks, just like many Asian cultures, especially those of low education and agrarian values (e.g. immigrants who came to the states before the 70s) may resist psychological, counseling or special education intervention as they consider them stigmatizing (Papadopoulos, 2009). Many Greek parents, especially those of first generation (who came from Greece or Cyprus, which is of Greek origins, language, and culture) may feel ashamed to disclose information about their children's special education status or may even deny this status of their child (Sprydakis, 1981). They feel that sensitive personal data may spread in the Greek community, especially if it is small. Greek-American communities are run by the Church so many parents may see their child's exceptionality through religious lenses and avoid any other 
context or intervention (Spyridakis, 1981). They may not resist or reject services within the public school system, but they may not accept any outside it (Papadopoulos, 2009).

The Greek Orthodox Church of America and its office of Greek education provide annual staff development training in many different teaching, classroom management, and special education skills, including ADHD, but the focus is still on the Greek language education and the American curriculum (like the one of the public schools) (Makedon, 2007). It also depends on the Principals' initiative to send their teachers to those training seminars. Also, every summer, the Greek Orthodox Archdiocesan Office of Education sends teachers to Cyprus for training (Makedon, 2007). Interventions in the parochial school and especially in the small afterschool program, but even in the public school system (e.g. NYS in the 90s) may are limited only in disciplinary actions, penalizing student with extra assignments, or by affecting grades or conduct remarks on report (NYS Dept. of Ed, 1992 - Zoupaniotis, 2012).

Modern Greek is a difficult language, with many archaic structures and affinities with ancient Greek, with different pronunciation and a different alphabet than English (EvangelinouYiannaki, \& O'Donoghue, 2011). It requires a certain amount of focus and mental effort, a lot of time and practice, especially if it is an afterschool or Saturday school program. For any child that would be hard, so one may imagine how it hard would be for a student with ADHD. If we add the rest of the Greek parochial curriculum, then we get the picture. As a result, the most crucial challenge for the Modern Greek teacher working with students is motivation. The picture gets even gloomier and more chaotic if we now also add other negative factors and misconceptions, such as: the underfunding and the lack of appropriate teachers and Principals or the tendency of many parents to see afterschool programs as places for babysitting, somewhere they can leave their kids when they are at work or the ignorance of many parents and community leaders whose goals for Greek education are more emotional and stem from nostalgia for the "Old Country" rather than genuine academic goals. Also, more and more unmotivated and at-risk students of non-Greek origin enter Greek schools not because they want to learn Greek, but because their parents place there for a better and safer future beyond the risks they face in various public schools, usually in ghettos or unsafe neighborhoods (Zoupaniotis, 2012). All these factors make the school lives of students with ADHD even harder. Thus, learning Greek is a double challenge for the student with ADHD and the teacher, both academic and behavioral.

\section{Teachers' Interventions for Success with Middle School Students who learn a Second or Foreign Language (i.e. Modern Greek)}

Some basic behavioral and classroom management interventions for Middle School students with ADHD are the following in terms of attention and selection: stay alert, ignore distractions, concentrate at the right time, plan and control impulses, and adjust their pace and control activity (Lanir, 2011).

Modifications in the classroom in order to accommodate students with ADHD may include some efforts from the teacher: remember names quickly and keep in mind some information about your students; be in class well ahead of your students; have small exercises ready as students enter. Also, ensure they go towards their class grade; start promptly with attendance; try to be well-organized with lesson plans, handouts, homework and student files; mark the initials on the board of those who are late, misbehave, forget materials. If they behave well, 
MULTILINGUAL ACADEMIC JOURNAL OF EDUCATION AND SOCIAL SCIENCES

Vol. 6, No. 1, 2018, E-ISSN: 2308-0876 @ 2018 KWP

then erase their initials, but still note down that they were late, etc. Also, keep clear documentation of completed work, homework handed in, absences, tardiness etc. Finally, ensure your students know that you keep this checklist up-to-date and keep exercises, assignments, within a time limit with clear instructions and grading methods (Lanir, 2011). Choose together six to eight of the most important classroom rules. Some of them can be the following: post those chosen, explain why and present the consequences for breaking them. Then give a copy to each student to sign that they are in agreement. Frequently review and keep the list of rules in view and refer to them if necessary. Make sure chosen expectations and consequences are fair, consistent and clear. Have a strong, structured, consistent and, therefore, predictable classroom routine. Also, continually reinforce acceptable and unacceptable behavior by: praising and rewarding good work and behavior (Lanir, 2011).

Utilizing collaborative learning may really help as we make a positive use of students' tendency to side-talk and being oversensitive to external stimuli to which they attach. We accomplish this by having these students in peer groups acting as leaders, facilitators or, in other words, role models to encourage on task behavior. Important is also to relentlessly following through with rules, consequences, praise and rewards (Lanir, 2011). Also, connecting to students, empathizing and developing a healthy rapport with the student and the parents are really crucial. Colleagues can help too, if they know some important information about the child's history and needs (Lanir, 2011).

The US Department of Education (2006) suggests some useful strategies for academic interventions when teaching language skills. For silent reading, establish a fixed time each day for silent-reading, follow-along reading. Ask the child to read a story silently while listening to other students or the teacher read the story aloud to the entire class. As Turketi (2010) put it, "an ADHD student is thus a socially impulsive person " $(\mathrm{p} 2)$. Collaborative learning can help in the form of partner reading activities in groups or pairs (US Department of Education, 2006).

Also, creative and artistic activities can turn student's impulsivity and hyperactivity into something positive. All this excessive energy that the student with ADHD may have can be utilized in doing something meaningful. So when we have a student with ADHD who wants to leave his or her seat, we can encourage him or her to do so in order to create, let's say, storyboards, where pages of stories are posted on boards with attractive colorful illustrations (US Department of Education, 2006). Essays of students can be displayed on holidays and various community activities as those are very dominant in the annual Greek school calendar. In storytelling, the child can retell a story and express him/herself (US Department of Education, 2006). That can be used in mythology, history, or practicing oral Modern Greek/conversation skills. Playacting can be easily used in Greek drama education and poem recitation which are extremely important and often used in holiday school events and activities (US Department of Education, 2006). Spelling and vocabulary activities can include "hard-to-read" sight-vocabulary words from the word bank that is a set of pieces of color paper on board with words and their meaning on the back can be used for hard Greek vocabulary and terminology for various Greek subjects (US Department of Education, 2006; Turketi, 2010). Also, Greek music and dance can help the fidgeting child positively use all its excessive energy bursts and socialize for both fun and learning.

Time management accommodations can be provided in a diverse classroom of different grades and language groups being in the same classroom as often happens in the Greek school, 
MULTILINGUAL ACADEMIC JOURNAL OF EDUCATION AND SOCIAL SCIENCES

Vol. 6, No. 1, 2018, E-ISSN: 2308-0876 @ 2018 KWP

where students may be few and each one with his or her own needs and different level of language (US Dep of Ed, 2006). Then, using independent tutoring strategies can help address time accommodation needs for students with ADHD. However, more than one teacher may be needed in the classroom.

Assistive technology recommended by the US Dept. Of Ed. (2006) may be the case for charter schools and public schools that are well funded, but may not be the case for underfunded Greek parochial schools which are the vast majority of US Greek education programs, run by the Church, whose least concern and least recipient of funds seems to be the Greek school (Zoupaniotis, 2012). In a small classroom of 5-10 students, I would suggest handy alternative to assistive technology, such as teacher's own ipad, ipod or laptop, though Principal's approval to such "unorthodox" practices may be an issue.

An interesting proposal for creative interdisciplinary Greek curriculum that draws a lot from community affairs and students' cultural experiences based on multicultural learning comes from a kind of old source as written in 1975, but still extremely fresh and creative: ideas for the classroom, such as lesson plans on the history of Greek-American immigration, Greek communities, mementos, photographs, and stories from grandparents. Thus, making the student with ADHD involved in a family and personal project, you make him or her less bored, the lesson less "book-smart" styled and more concrete and fun. Thus, the student feels more connected and his or her energy bursts and fidgeting are channeled in positive and healthy kinesthetic ways while inattention and trouble remembering or focusing are addressed by making stronger emotionally, spiritually, and culturally enhanced associations in a concrete multicultural and whole-person perspective. This project reported success with both Greek and non-Greek students who equally found it an interesting multicultural and academically, culturally and spiritually enriched experience that left its positive and rewarding mark in those students' lives (FSU, 1975).

\section{Conclusion}

In conclusion, as it is already said, while motivation of tired and exhausted students who come to the afterschool program after the public school to learn a whole different universe of demanding and exotic curriculum, the Greek curriculum is a great source of motivation strategies and community activities, as the Greek school calendar is overloaded with national and religious holidays that require a long array of school events, concerts, community activities, and religious services that may connect families, school, communities, local Greek-American associations and local parishes in a very interactive, lively, vivid network of cultural, academic, and spiritual support. For a Greek-speaking student who learns ESL, English may not sound as exotic as Greek may sound in the USA, since we live in the age of globalization and the Web. That may apply even in the Greek province. However, language is intertwined with culture and certain aspects of cultural experience that cannot be experienced online could still be viewed as exotic and challenging especially for a student with ADHD-ADD Type who has difficulty concentrating. The same strategies, methodologies, materials and resources can be used of learning any second or foreign language including. Especially, when the students are Greek, then we are talking about the same linguistic interaction but in reverse! Even for the non-Greek student with ADHD, whether the student is an ESL non-Greek or a GSL non-Greek, finding a new community, a new support system and learning something stimulating and academically 
MULTILINGUAL ACADEMIC JOURNAL OF EDUCATION AND SOCIAL SCIENCES

Vol. 6, No. 1, 2018, E-ISSN: 2308-0876 @ 2018 KWP

demanding may give them a sense of purpose, sense of self-esteem and pride overcoming disability limitations. They may also get a sense of equality sharing a type of "white" culture which however is also a minority culture at the same time, far different from the "dead male white Greek culture" that is often portrayed in the mainstream learning arena and trace affinities between their own culture and other cultures, such as the Greek one. Thus, both unmotivated students and parents who may have thought of the underfunded Greek classroom as a babysitting place or equivalent to chores or "busy work" chores, may use it in an effective way that for a student with ADHD and developmental challenges such as those of the Middle School may become actually a positive experience that enriches the student's academic strengths and builds social, community, and spiritual roles and identities with some collaboration and effort by the teacher and the school community, as the literature suggested above.

\section{References}

American Psychiatric Association. (2000). Diagnostic and statistical manual of mental disorders (4th ed., text rev.). Washington, DC: Author.

Council of Greeks Abroad (SAE). (2007-2012). USA: Greek-American population (de jure translation from Greek). Retrieved from: http://www.sae.gr/?id=13227\&tag=\%CE\% 97.\%CE\%A0.\%CE\%91.

ERIC. (1998). Teaching Children with Attention Deficit/Hyperactivity Disorder: Update 1998. ERIC Digest E569.Retrieved from: http://www.eric.ed.gov/PDFS/ED423633.pdf

Evangelinou-Yiannaki, A., \& O'Donoghue, T. (2011). A Qualitative Study of the Teaching of Modern Greek in Western Australia under the 'Seconded Teachers from Greece Scheme': Implications for Other Similar Schemes. Australian Journal of Teacher Education, 36, 1, 1-12. Retrieved from:http://www.eric.ed.gov/PDFS/EJ943404.pdf

Florida State University. (1975). A Project in Multicultural Learning: GreekAmericanContributions to American Society. Office of Education (DHEW), Washington, DC. Retrieved from:http://www.eric.ed.gov/ERICWebPortal/search/recordDetails.jsp? searchtype=advanced\&pageSize=10\&ERICExtSearch_Operator_2=and\&ERICExtSearch_ Operator_1=and\&ERICExtSearch_EDEJSearch=elecBoth\&ERICExtSearch_SearchType_2 =kw\&eric_displayStartCount=1\&ERICExtSearch_SearchValue_2=Greek-

American\&ERICExtSearch_SearchType_1=kw\&ERICExtSearch_SearchType_0=kw\&ERIC

ExtSearch_FullText=true\&ERICExtSearch_PubDate_From=0\&ERICExtSearch_PubDate_T o=2012\&ERICExtSearch_SearchCount=2\&_pageLabel=RecordDetails\&objectld=090001 9b80042d36\&accno=ED208090\&_nfls=false

Hill, J. (2011). Prevalence of Aggression and Defiance in Children with ADD/ADHD Tendencies. Wayland Baptist University June 2. Retrieved from: http://www.eric.ed.gov/PDFS/ED520253.pdf

Kalyva, E. (2008). Special Education: What do Greek Teachers Know about Learning Disabilities, Autism, and Attention-Deficit/Hyperactivity Disorder? City College, Affiliated Institution of the University of Sheffield. Retrieved from:http://cirrie.buffalo.edu/encyclopedia/en/article/263/

Lanir, L. (2011). ADD/ADHD Students - Foreign Language Classroom Management. Retrieved from: 
MULTILINGUAL ACADEMIC JOURNAL OF EDUCATION AND SOCIAL SCIENCES

Vol. 6, No. 1, 2018, E-ISSN: 2308-0876 @ 2018 KWP

http://lesley-lanir.suite101.com/addadhd-students---foreign-language-classroommanagement-a327724.

Makedon, M. (2007). Archdiocesan District Office of Education Report. April 26-27. GreekOrthodox Archdiocese of America: Huston, TX. Retrieved from:http://www. goarch.org/archdiocese/departments/education/reports/AC\%20REPORT_Houston-TXApr_07.pdf

New York State Education Dept., Albany. Office for Special Education Services. (1992). A Parent's Guide to Special Education for Children Ages 5-21: Your Child's Right to an Education in New York State. Non-English Language Editions. Retrieved from: http://www.eric.ed.gov/ERICWebPortal/search/recordDetails.jsp?searchtype=advance d\&pageSize=10\&ERICExtSearch_Operator_2=and\&ERICExtSearch_SearchValue_0=disa bilities\&ERICExtSearch_Operator_1=and\&ERICExtSearch_SearchType_2=kw\&eric_displ ayStartCount=11\&ERICExtSearch_SearchType_1=kw\&ERICExtSearch_SearchValue_2=G reek\&ERICExtSearch_SearchType_0=kw\&ERICExtSearch_FullText=true\&ERICExtSearch _PubDate_From=0\&ERICExtSearch_PubDate_To=2012\&ERICExtSearch_SearchCount $=1$ \&_pageLabel=RecordDetails\&objectld=0900019b80402b03\&accno=ED359690\&_nfls=f alse

Papadopoulos, C. (2009). Stigma towards people with mental health problems: An individualism-collectivism cross-cultural comparison. Doctoral dissertation submitted at the School of Health and Social Sciences, Middlesex University. Retrieved from:http://eprints.mdx.ac.uk/6253/1/Papadopoulosstigma_towards_people_with_mental_health_problems_PhD.pdf

Partnership for Afterschool Education (PASE). (n.d.). New York City Family Guide to Afterschool Programs. Retrieved from:

http://www.pasesetter.com/publicationResources/Publications/PDF/NYC\%20Guide\%2 Oto\%20ASP/NYC\%20Family\%20Guide\%20to\%20Afterschool\%20Programs.pdf

Smith, R. L. (n.d.). Teaching Middle School Students with ADHD. University of Florida: FL. Retrieved from: http://mypage.iu.edu/ rllsmith/ADHDweb.htm

Spiridakis, J. D. (1981). Special Education for the Greek Bilingual Child: Greece, Cyprus and the United States. Paper presented at The Council for Exceptional Children Conference on The Exceptional Bilingual Child (New Orleans, LA, February, 1981, Session F-3). Retrieved from:

http://www.eric.ed.gov/ERICWebPortal/search/record

Details.jsp?searchtype=advanced\&pageSize=10\&ERICExtSearch_Operator_2=and\&ERI CExtSearch_SearchValue_0=disabilities\&ERICExtSearch_Operator_1=and\&ERICExtSear ch_SearchType_2=kw\&eric_displayStartCount=11\&ERICExtSearch_SearchType_1=kw\& ERICExtSearch_SearchValue_2=Greek\&ERICExtSearch_SearchType_0=kw\&ERICExtSear ch_FullText=true\&ERICExtSearch_PubDate_From=0\&ERICExtSearch_PubDate_To $=2012$ \&ERICExtSearch_SearchCount=1\&_pageLabel=RecordDetails\&objectld=0900019b8004 20a5\&accno=ED204878\&_nfls=false

Thompson, L. C. (1997). Foreign Language Assessment in Grades K-8: An Annotated Bibliography of Assessment Instruments. Language in Education: Theory and Practice 90. Delta Systems Inc.: IL. Retrieved 
MULTILINGUAL ACADEMIC JOURNAL OF EDUCATION AND SOCIAL SCIENCES

Vol. 6, No. 1, 2018, E-ISSN: 2308-0876 @ 2018 KWP

from:http://www.eric.ed.gov/ERICWebPortal

/search/recordDetails.jsp?searchtype=advanced\&pageSize=10\&ERICExtSearch_Operat or_2=and\&ERICExtSearch_SearchValue_0=modern+Greek\&ERICExtSearch_SearchType _2=kw\&ERICExtSearch_Operator_1=and\&eric_displayStartCount=21\&ERICExtSearch_S earchType_1=kw\&ERICExtSearch_SearchType_0=kw\&ERICExtSearch_FullText=true\&ER ICExtSearch_PubDate_From=0\&ERICExtSearch_PubDate_To=2012\&ERICExtSearch_Sea rchCount=1\&_pageLabel=RecordDetails\&objectld=0900019b800afb08\&accno=ED4137 $68 \&$ nfls=false

Turketi, N. (2010). Teaching English To Children With ADHD. (Master's Thesis). School for International Training Brattleboro, Vermont USA Retrieved from: http://digitalcollections.sit.edu/cgi/viewcontent.cgi?article=1489\&context=ipp_collecti on\&seiredir=1\&referer=http\%3A\%2F\%2Fwww.google.com\%2Furl\%3Fsa\%3Dt\%26rct\%3 Dj\%26q\%3Dcreative\%2520teaching\%2520foreign\%2520language\%2520to\%2520stude nts\%2520with\%2520adhd\%2520full\%2520pdf\%26source\%3Dweb\%26cd\%3D1\%26ved \%3D0CCoQFjAA\%26url\%3Dhttp\%253A\%252F\%252Fdigitalcollections.sit.edu\%252Fcgi\% 252Fviewcontent.cgi\%253Farticle\%253D1489\%2526context\%253Dipp_collection\%26ei \%3DAtZ_T6fglcPn0QGz3uCiCA\%26usg\%3DAFQjCNEbvDzrcJA94_2JClabnsk80UglmQ\#se arch=\%22creative\%20teaching\%20foreign\%20language\%20students\%20adhd\%20full\% $20 \mathrm{pdf} \% 22$

U.S. Department of Education. (2006). Teaching Children with Attention Deficit Hyperactivity Disorder: Instructional Strategies and Practices. Retrieved from:

http://www2.ed.gov/rschstat/research/pubs/adhd/adhd-teaching-2006.pdf

Zoupaniotis, A. (2012). Greek-American Community: We either change or we sink. Greek American News Agency (de jure translation from Greek).

This paper is based on a term paper submitted for the MA in Rehabilitation Counseling Program (School of Education, Counseling \& Guidance Dept.) at the New Mexico Highlands University (NMHU) (2010-2013). 